\title{
Rheinheimera texasensis sp. nov., a halointolerant freshwater oligotroph
}

Correspondence
Robert J. C. McLean
McLean@txstate.edu

\author{
Mubina M. Merchant, $†$ Allana K. Welsh and Robert J. C. McLean \\ Department of Biology, Texas State University - San Marcos, 601 University Drive, San Marcos, \\ TX 78666, USA
}

\begin{abstract}
A Gram-negative, rod-shaped, motile, non-spore-forming bacterium, designated strain $A 62-14 B^{\top}$, was isolated from a constant-temperature, spring-fed, freshwater lake. On the basis of the complete 16S rRNA gene sequence, strain $A 62-14 \mathrm{~B}^{\top}$ was shown to belong to the class Gammaproteobacteria, being most closely related to Rheinheimera sp. HTB082 (96.2\% sequence similarity), Rheinheimera baltica (95.01\%), Rheinheimera pacifica (96.35\%), Rheinheimera perlucida and Alishewanella fetalis (95.9\%). The major fatty acids $\left(\mathrm{C}_{16: 1} \omega 7 c\right.$, $\left.38.56 \% ; \mathrm{C}_{16: 0}, 19.04 \% ; \mathrm{C}_{12: 0} 3-\mathrm{OH}, 12.83 \% ; \mathrm{C}_{18: 1} \omega 7 c, 7.70 \%\right)$ and the motility of strain A62-14 $\mathrm{B}^{\top}$ support its affiliation to the genus Rheinheimera. The salt intolerance of strain $A 62-14 B^{\top}$, together with the results of other physiological and biochemical tests, allowed the differentiation of this strain from the three species of the genus Rheinheimera with validly published names. Therefore strain $\mathrm{A} 62-14 \mathrm{~B}^{\mathrm{T}}$ represents a novel species of the genus Rheinheimera, for which the name Rheinheimera texasensis sp. nov. is proposed. The type strain is $\mathrm{A} 62-14 \mathrm{~B}^{\top}$ (=ATCC BAA $-1235^{\top}=\mathrm{DSM} 17496^{\top}$ ). The description of the genus Rheinheimera is emended to reflect the halointolerance and freshwater origin of strain $A 62-14 B^{\top}$.
\end{abstract}

The genus Rheinheimera was first proposed by Brettar et al. (2002) and, at the time of writing, contains three species, Rheinheimera baltica (Brettar et al., 2002), Rheinheimera pacifica (Romanenko et al., 2003) and Rheinheimera perlucida (Brettar et al., 2006), all of which are of marine origin. On the basis of $16 \mathrm{~S}$ rRNA gene sequence comparisons, members of the genus Rheinheimera are related to a clinical isolate, Alishewanella fetalis (Fonnesbech Vogel et al., 2000), and an alkaliphilic psychrophile, 'Arsukibacterium ikkense' (Schmidt et al., 2007). A new isolate, strain $\mathrm{A} 62-14 \mathrm{~B}^{\mathrm{T}}$, is described in this paper and is proposed as a novel member of the genus Rheinheimera on the basis of the recommendations for the description of a novel species given by Kämpfer et al. (2003).

Strain $\mathrm{A} 62-14 \mathrm{~B}^{\mathrm{T}}$ was isolated from Spring Lake in San

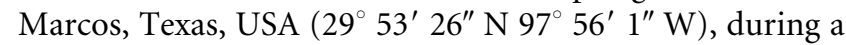
study of freshwater bacteria capable of colonizing dialysis tubing in response to acylated homoserine lactones (McLean et al., 2005). The strain was isolated on R2A agar (Difco) after incubation for $48 \mathrm{~h}$ at $30{ }^{\circ} \mathrm{C}$ and produced white, semi-transparent colonies. Subculturing was performed on R2A agar incubated for $48 \mathrm{~h}$ at $25^{\circ} \mathrm{C}$

tPresent address: Qiagen Inc., 27220 Turnberry Lane, Suite 200, Valencia, CA 91355, USA.

The GenBank/EMBL/DDBJ accession number for the 16S rRNA gene sequence of strain $A 62-14 B^{\top}$ is $A Y 701891$.

An expanded phylogenetic tree for strain $A 62-14 B^{\top}$ and related taxa is available with the online version of this paper. and 7 days at $20{ }^{\circ} \mathrm{C}$. On R2A agar, strain $\mathrm{A} 62-14 \mathrm{~B}^{\mathrm{T}}$ was able to grow at temperatures in the range $20-37{ }^{\circ} \mathrm{C}$. No growth was seen at 4,42 or $55^{\circ} \mathrm{C}$. Limited growth was seen on dilute $(10 \%, \mathrm{w} / \mathrm{v})$ tryptone soy agar after $48 \mathrm{~h}$ at $30{ }^{\circ} \mathrm{C}$. No other media tested [brain-heart infusion agar, fullstrength tryptone soy agar, Luria-Bertani agar, nutrient agar (all from Difco) and Biolog universal growth media (Biolog)] (Amy et al., 1992) could support growth of strain $\mathrm{A} 62-14 \mathrm{~B}^{\mathrm{T}}$. The organism grew between $\mathrm{pH} 6.5$ and 9.6, with optimal growth occurring at $\mathrm{pH} 7.5-8.0$. No growth was observed at $\mathrm{pH}$ 5.0. The novel strain could not grow in the presence of $\mathrm{NaCl}$ at concentrations greater than $1 \%$ $(\mathrm{w} / \mathrm{v})$. Gram staining was performed using a standard protocol (Doetsch, 1981).

Cell morphology was observed using a Zeiss microscope at a magnification of $\times 1000$, using cells grown overnight on R2A agar at $30{ }^{\circ} \mathrm{C}$. Motility was observed by examining a wet-mount slide preparation of strain $\mathrm{A} 62-14 \mathrm{~B}^{\mathrm{T}}$ with a Zeiss microscope at $\times 800$, using both phase-contrast and dark-field optics. Dilute suspensions of strain A62-14B and related organisms, namely $R$. pacifica KMM $1406^{\mathrm{T}}$ [obtained from the Culture Collection of the University of Göteborg, Sweden, and cultured overnight at $30{ }^{\circ} \mathrm{C}$ on brain-heart infusion agar (Difco)] and Alishewanella fetalis ATCC BAA-284 ${ }^{\mathrm{T}}$ (obtained from the American Type Culture Collection, USA, and cultured overnight at $37{ }^{\circ} \mathrm{C}$ on brain-heart infusion agar), were examined for the presence of flagella and pili by using negative staining and transmission electron microscopy (Tolson et al., 1995). The 

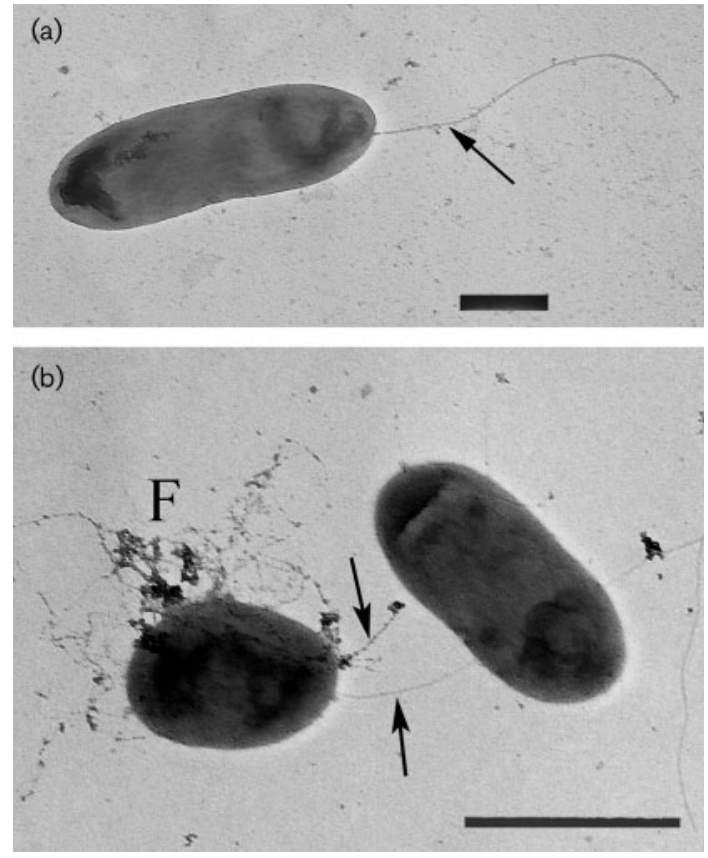

Fig. 1. Transmission electron micrographs of cells of strain A62$14 \mathrm{~B}^{\top}$ showing a single polar flagellum (a) and multiple polar and lateral flagella (b) (indicated by arrows in both pictures). Filaments (F) are also seen between some adjacent cells. Contrast was optimized using Adobe Photoshop, version 7.0.1 (Adobe Systems). Bars, $1 \mu \mathrm{m}$.

transmission electron microscopy examination revealed that cells of strain $\mathrm{A} 62-14 \mathrm{~B}^{\mathrm{T}}$ have either single polar flagella (Fig. 1a) or multiple polar and lateral flagella; occasionally, filaments were seen between cells lying in close proximity (Fig. 1b). Cells of R. pacifica KMM $1406^{\mathrm{T}}$ had single polar flagella, but no flagella were seen on cells of Alishewanella fetalis ATCC BAA- $284^{\mathrm{T}}$ (data not shown).

For 16S rRNA gene sequencing, cultures were grown for $16 \mathrm{~h}$ at $30{ }^{\circ} \mathrm{C}$ in R2A broth. DNA was extracted using the DNeasy tissue kit (Qiagen). The 16S rRNA gene was amplified using primers EUB7F and 1492R, as described elsewhere (Lane, 1991). The PCR products were purified using a minElute gel extraction kit (Qiagen). Sequencing was performed using a DNA sequencer (model 377; Applied Biosystems) and a BigDye cycle sequencing kit (version 3.1; Perkin-Elmer Biosystems); the $1447 \mathrm{bp}$ sequence was aligned with related sequences obtained from GenBank and EMBL by using BLAST and FASTA searches (Altschul et al., 1997; Pearson \& Lipman, 1988) using Sequencher 4.2.2 (Gene Codes Corporation) and CLUSTAL_X (Thompson et al., 1997). Using the MrModeltest program, version 2.2 (Nylander, 2004), the GTR + I + G model of sequence evolution was found to best fit this dataset. Phylogenetic analyses (Fig. 2) were performed using PAUP 4.0b10 with distance-based neighbour-joining, maximum-parsimony and maximum-likelihood methods (Swofford, 2002). Confidence in the topology obtained from these analyses was gauged using bootstrap resampling methods in PAUP and included 10000 replications (1000 replications for the maximum-likelihood tree) and a full heuristic search. Only those bootstrap percentages of at least $70 \%$ were retained, as they demonstrate good support (Hillis \& Bull, 1993). Bayesian analysis was completed using MRBAYES (version 3.0) and a $90 \%$ majority rule consensus tree was generated from this treefile in PAUP

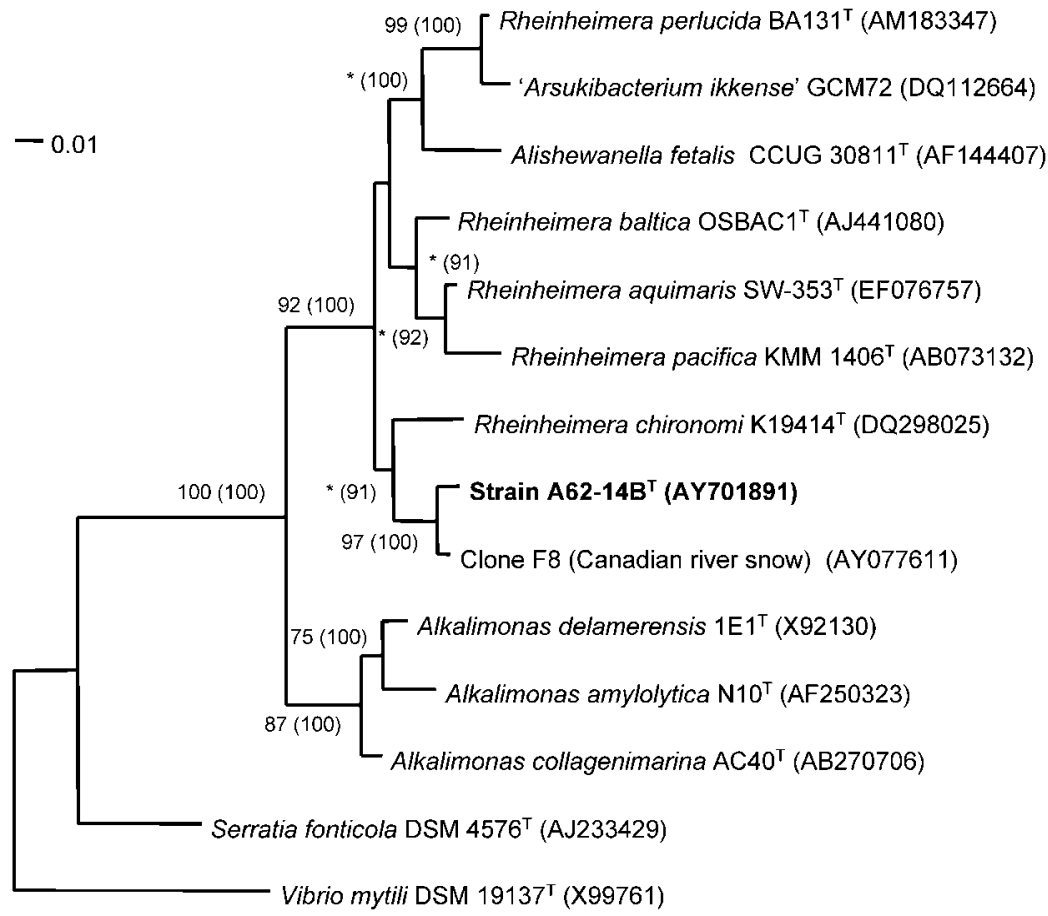

Fig. 2. Maximum-likelihood phylogenetic tree of strain $A 62-14 B^{\top}$ and the most closely related cultured organisms, created using PAUP $4.0 \mathrm{~b} 10$ and a GTR $+\mathrm{I}+\mathrm{G}$ model of sequence evolution (Swofford, 2002). Numbers reflect bootstrap support percentages (of 1000 replications) generated in PAUP; numbers in parentheses are Bayesian posterior probabilities created using MRBAYES, version 3.0 (Huelsenbeck \& Ronquist, 2001). Asterisks indicate that the branch could not be resolved by neighbour-joining analysis. Vibrio mytili DSM $19137^{\top}$ (GenBank accession number X99761) was used as an outgroup. An expanded phylogenetic analysis which includes sequences from cultured and uncultured organisms is available with the online version of this paper (see Supplementary Fig. S1). 
(Huelsenbeck \& Ronquist, 2001). Fig. 2 shows a representative analysis of closely related cultured species (see Supplementary Fig. S1, available at IJSEM Online, for a full analysis with cultured and uncultured bacterial sequences).

Strain $\mathrm{A} 62-14 \mathrm{~B}^{\mathrm{T}}$ most closely resembled an unclassified, filament-producing, gammaproteobacterium designated strain F8 (GenBank accession number AY077611) that had also been isolated from a freshwater environment (Böckelmann et al., 2006). Here, the three recognized species of the genus Rheinheimera and strain $\mathrm{A} 62-14 \mathrm{~B}^{\mathrm{T}}$ partitioned into four distinct clades. Only the Bayesian analyses partially resolved the relationships between the recognized species of the genus Rheinheimera and their close relatives. As noted by Brettar et al. (2006), the phylogenetic position of strain $\mathrm{A} 62-14 \mathrm{~B}^{\mathrm{T}}$ was unstable with respect to the genus Alishewanella, as demonstrated by a lack of bootstrap support in the neighbour-joining, maximum-parsimony and maximum-likelihood analyses.
Metabolic profiles for preferred carbon, nitrogen, phosphorous and sulfur sources were obtained by the use of the phenotype microarray technique (Bochner et al., 2001). An isolate of strain $\mathrm{A} 62-14 \mathrm{~B}^{\mathrm{T}}$ was cultured on $\mathrm{R} 2 \mathrm{~A}$ agar and shipped to Biolog (USA) for phenotype microarray testing of approximately 1000 characteristics. Duplicate phenotype microarray readings were recorded for $24 \mathrm{~h}$ and kinetic data were analysed with proprietary software. The cellular fatty acids were determined at MIDI Laboratories (USA) by using fatty acid methyl ester analysis (Norton \& LeChevallier, 2000). Strain A62-14B ${ }^{\mathrm{T}}$ grew on R2A agar, but, unlike $R$. baltica, $R$. pacifica, $R$. perlucida and Alishewanella fetalis, did not grow on marine agar or Luria-Bertani agar. As a result, comparison of the fatty acid profiles of these species is limited by differences in growth conditions. The metabolic profiles are summarized in Table 1 and in the species description. As strain A62-14B ${ }^{\mathrm{T}}$ is generally salt-intolerant, we provide an emended description for the genus Rheinheimera based on the

Table 1. Phenotypic characteristics used to distinguish strain $A 62-14 B^{\top}$ from related species

Taxa: 1, strain A62-14B $\mathrm{B}^{\mathrm{T}}$ (data from this study); 2, R. baltica OSBAC1 ${ }^{\mathrm{T}}$ (Brettar et al., 2002); 3, R. pacifica KMM 1406 ${ }^{\mathrm{T}}$ (Romanenko et al., 2003); 4 , R. perlucida BA131 ${ }^{\mathrm{T}}$ (Brettar et al., 2006); 5, Alishewanella fetalis CCUG 30811 ${ }^{\mathrm{T}}$ (Fonnesbech Vogel et al., 2000; Romanenko et al., 2003). +, Positive; -, negative; ND, no data available.

\begin{tabular}{|c|c|c|c|c|c|}
\hline Characteristic & 1 & 2 & 3 & 4 & 5 \\
\hline $\mathrm{O}_{2}$ requirement & Facultative & Aerobic & Aerobic & Facultative & Facultative \\
\hline Pigmentation & None & Blue & None & None & None \\
\hline \multicolumn{6}{|l|}{ Cell size $(\mu \mathrm{m})$ : } \\
\hline Length & $1.25-2.5$ & $1.8-2.0$ & $0.9-4.5$ & $0.9-2.4$ & 2.0 \\
\hline Width & $0.7-0.8$ & $0.5-1.5$ & $0.6-0.8$ & $0.6-1.2$ & $0.5-1.0$ \\
\hline Motility & + & + & + & + & - \\
\hline Flagella & $\begin{array}{l}\text { Single polar or multiple } \\
\text { polar and lateral }\end{array}$ & Single polar & $\begin{array}{l}\text { Multiple polar } \\
\text { and lateral }\end{array}$ & Single polar & None \\
\hline \multicolumn{6}{|l|}{ Temperature for growth $\left({ }^{\circ} \mathrm{C}\right)$ : } \\
\hline Range & $25-37$ & $4-30$ & $4-37$ & $4-37$ & $25-41$ \\
\hline Optimum & $30-37$ & $20-25$ & ND & $20-30$ & $\mathrm{ND}$ \\
\hline \multicolumn{6}{|l|}{$\mathrm{pH}$ for growth: } \\
\hline Range & $6.5-9.6$ & $5.7-10$ & ND & $5.7-10$ & ND \\
\hline Optimum & $7.5-8.0$ & 7 & ND & 7 & ND \\
\hline \multicolumn{6}{|c|}{$\mathrm{NaCl}$ concentration for growth $(\%, \mathrm{w} / \mathrm{v})$ : } \\
\hline Range & $0-1$ & $0-6$ & $0-8$ & $0-8$ & $3-8$ \\
\hline Optimum & 0 & $1-3$ & $\mathrm{ND}$ & $1-3$ & ND \\
\hline Starch hydrolysis & + & + & + & + & - \\
\hline Reduction of nitrate to nitrite & + & - & - & + & + \\
\hline \multicolumn{6}{|l|}{ Assimilation of: } \\
\hline $\mathrm{N}$-Acetylglucosamine & + & + & + & + & - \\
\hline Arabinose & + & - & + & - & ND \\
\hline Cellobiose & + & - & - & - & ND \\
\hline Citrate, glycerol & - & - & + & - & ND \\
\hline Maltose & - & + & + & - & $\mathrm{ND}$ \\
\hline DNA G $+C$ content $(\mathrm{mol} \%)$ & 48.2 & 48.9 & 49.6 & 48.9 & 50.6 \\
\hline Major fatty acids $(>5 \%)$ & $\begin{array}{c}\mathrm{C}_{16: 1} \omega 7 c, \mathrm{C}_{16: 0}, \mathrm{C}_{12: 0} \\
3-\mathrm{OH}, \mathrm{C}_{18: 1} \omega 7 c \\
\mathrm{C}_{17: 1} \omega 8 c\end{array}$ & $\begin{array}{c}\mathrm{C}_{16: 1} \omega 7 c, \mathrm{C}_{16: 0} \\
\mathrm{C}_{18: 1} \omega 7 c\end{array}$ & $\begin{array}{c}\mathrm{C}_{16: 0}, \mathrm{C}_{17: 0}, \\
\mathrm{C}_{16: 1} \omega 7 c, \\
\mathrm{C}_{18: 1} \omega 7 c, \mathrm{C}_{17: 1} \omega 8 c\end{array}$ & $\begin{array}{c}\mathrm{C}_{16: 1} \omega 7 c, \mathrm{C}_{16: 0} \\
\mathrm{C}_{17: 1} \omega 8 c \\
\mathrm{C}_{18: 1} \omega 7 c\end{array}$ & $\begin{array}{c}\mathrm{C}_{17: 1} \omega 8 c, \mathrm{C}_{16: 1} \omega 7 c, \\
\mathrm{C}_{17: 0}, \mathrm{C}_{16: 0}, \\
\mathrm{C}_{18: 1} \omega 7 c\end{array}$ \\
\hline
\end{tabular}


current study and that of Brettar et al. (2002). On the basis of the data from this study, strain $\mathrm{A} 62-14 \mathrm{~B}^{\mathrm{T}}$ represents a novel species of the genus Rheinheimera, for which the name Rheinheimera texasensis sp. nov. is proposed.

\section{Emended description of the genus Rheinheimera}

Rheinheimera (Rhein.hei'me.ra. N.L. n. Rheinheimera named after the German marine microbiologist Gerhard Rheinheimer, in recognition of his work on marine and estuarine bacteria).

The description of the genus Rheinheimera is as given by Brettar et al. (2002) but with the following changes. Of freshwater, estuarine or marine origin. $\mathrm{NaCl}$ supports growth, except in the case of one species, but strains are not tolerant of high salinities $(>6 \%)$.

\section{Description of Rheinheimera texasensis sp. nov.}

Rheinheimera texasensis (tex.as.en'sis. N.L. fem. adj. texasensis pertaining to Texas, the location from which the organism was first isolated).

Cells are Gram-negative, rod-shaped, 1.2-2.5 $\mu \mathrm{m}$ long and $0.7-0.8 \mu \mathrm{m}$ wide, with single polar flagella or several polar and lateral flagella. Facultatively anaerobic. Network of filaments noted among cells lying in close proximity. After $24 \mathrm{~h}$ growth on $\mathrm{R} 2 \mathrm{~A}$ agar at $37{ }^{\circ} \mathrm{C}$, colonies are $1-2 \mathrm{~mm}$ in diameter, smooth, non-pigmented, transparent, raised and circular with entire margins. Optimal growth occurs between 30 and $37{ }^{\circ} \mathrm{C}$, with slow growth occurring at 20 $25{ }^{\circ} \mathrm{C}$ and no growth above $40{ }^{\circ} \mathrm{C}$. Withstands $\mathrm{pH}$ levels from 6.5 to 9.6, with optimal growth occurring at $\mathrm{pH} 7.5$ 8.0. No growth occurs at $\mathrm{NaCl}$ concentrations above $1 \%$ $(\mathrm{w} / \mathrm{v})$. Carbon sources utilized include $N$-acetylglucosamine, Tweens 20, 40 and 80, D-glucose, D-lactose, Dgalactose, sucrose, trehalose, methyl pyruvate, $\beta$-cyclodextrin, laminarin, glycogen and palatinose; citrate is not utilized. The type strain is positive in tests for starch and gelatin hydrolysis, nitrate reduction and oxidase and catalase activities. Indole production is not detected. The DNA G $+\mathrm{C}$ content of the type strain is $48.2 \mathrm{~mol} \%$. The predominant fatty acids are $\mathrm{C}_{16: 1} \omega 7 c(38.6 \%), \mathrm{C}_{16: 0}(19.0 \%), \mathrm{C}_{12: 0} 3-\mathrm{OH}(12.8 \%)$, $\mathrm{C}_{18: 1} \omega 7 c(7.7 \%), \mathrm{C}_{17: 1} \omega 8 c(3.8 \%), \mathrm{C}_{12: 0}(2.0 \%)$ and $\mathrm{C}_{18: 0}(2.0 \%)$.

The type strain, A62-14B ${ }^{\mathrm{T}}$ (=ATCC BAA- $1235^{\mathrm{T}}=\mathrm{DSM}$ $17496^{\mathrm{T}}$ ), was isolated from Spring Lake, a freshwater lake in San Marcos, Texas, USA.

\section{Note added in proof}

Since this paper was accepted for publication, two further novel species of the genus Rheinheimera have been described, Rheinheimera aquimaris (Yoon et al., 2007) and Rheinheimera chironomi (Halpern et al., 2007).

\section{Acknowledgements}

This study was made possible by a US Air Force subcontract (to R. J. C. M.) from Sam Houston State University. R. J. C. M. dedicates this paper to Professor Robert G. E. Murray for his outstanding contributions to our knowledge of bacterial taxonomy and ultrastructure.

\section{References}

Altschul, S. F., Madden, T. L., Schaffer, A. A., Zhang, J., Zhang, Z., Miller, W. \& Lipman, D. J. (1997). Gapped BLAST and PSI-BLAST: a new generation of protein database search programs. Nucleic Acids Res 25, 3389-3402.

Amy, P. S., Haldeman, D. L., Ringelberg, D., Hall, D. H. \& Russell, C. (1992). Comparison of identification systems for classification of bacteria isolated from water and endolithic habitats within the deep subsurface. Appl Environ Microbiol 58, 3367-3373.

Bochner, B. R., Gadzinski, P. \& Panomitros, E. (2001). Phenotype microarrays for high-throughput phenotypic testing and assay of gene function. Genome Res 11, 1246-1255.

Böckelmann, U., Janke, A., Kuhn, R., Neu, T. R., Wecke, J., Lawrence, J. R. \& Szewzyk, U. (2006). Bacterial extracellular DNA forming a defined network-like structure. FEMS Microbiol Lett 262, 31-38.

Brettar, I., Christen, R. \& Höfle, M. G. (2002). Rheinheimera baltica gen. nov., sp. nov., a blue-coloured bacterium isolated from the central Baltic Sea. Int J Syst Evol Microbiol 52, 1851-1857.

Brettar, I., Christen, R. \& Höfle, M. G. (2006). Rheinheimera perlucida sp. nov., a marine bacterium of the Gammaproteobacteria isolated from surface water of the central Baltic Sea. Int J Syst Evol Microbiol 56, 2177-2183.

Doetsch, R. N. (1981). Determinative methods of light microscopy. In Manual of Methods for General Bacteriology, pp. 21-33. Edited by P. Gerhardt, R. G. E. Murray, R. N. Costilow, E. W. Nester, W. A. Wood, N. R. Krieg \& G. B. Phillips. Washington, DC: American Society for Microbiology.

Fonnesbech Vogel, B., Venkateswaran, K., Christensen, H., Falsen, E., Christiansen, G. \& Gram, L. (2000). Polyphasic taxonomic approach in the description of Alishewanella fetalis gen. nov., sp. nov., isolated from a human foetus. Int J Syst Evol Microbiol 50, 1133-1142.

Halpern, M., Senderovich, Y. \& Snir, S. (2007). Rheinheimera chironomi sp. nov., isolated from a chironomid (Diptera; Chironomidae) egg mass. Int J Syst Evol Microbiol 57, 1872-1875.

Hillis, D. M. \& Bull, J. J. (1993). An empirical test of bootstrapping as a method for assessing confidence in phylogenetic analysis. Syst Biol 42, 182-192.

Huelsenbeck, J. P. \& Ronquist, F. (2001). MRBAYES: Bayesian inference of phylogenetic trees. Bioinformatics 17, 754-755.

Kämpfer, P., Buczolits, S., Albrecht, A., Busse, H.-J. \& Stackebrandt, E. (2003). Towards a standardized format for the description of a novel species (of an established genus): Ochrobactrum gallinifaecis sp. nov. Int J Syst Evol Microbiol 53, 893-896.

Lane, D. J. (1991). 16S/23S rRNA sequencing. In Nucleic Acid Techniques in Bacterial Systematics, pp. 115-175. Edited by E. Stackebrandt \& M. Goodfellow. New York: Wiley.

McLean, R. J. C., Barnes, M. B., Windham, M. K., Merchant, M. M., Forstner, M. R. J. \& Fuqua, C. (2005). Cell-cell influences on bacterial community development in aquatic biofilms. Appl Environ Microbiol 71, 8987-8990.

Norton, C. D. \& LeChevallier, M. W. (2000). A pilot study of bacteriological population changes through potable water treatment and distribution. Appl Environ Microbiol 66, 268-276. 
Nylander, J. A. A. (2004). MrModeltest 2.2. Distributed by the author. Evolutionary Biology Centre, Uppsala University, Sweden. http:// people.scs.fsu.edu/ nylander/mrmodeltest $2 /$ mrmodeltest $2 . h t m l$

Pearson, W. R. \& Lipman, D. J. (1988). Improved tools for biological sequence comparison. Proc Natl Acad Sci U S A 85, 2444-2448.

Romanenko, L. A., Uchino, M., Falsen, E., Zhukova, N. V., Mikhailov, V. V. \& Uchimura, T. (2003). Rheinheimera pacifica sp. nov., a novel halotolerant bacterium isolated from deep sea water of the Pacific. Int J Syst Evol Microbiol 53, 1973-1977.

Schmidt, M., Prieme, A. \& Stougaard, P. (2007). Arsukibacterium $i k k e n s e$ gen. nov., sp. nov, a novel alkaliphilic, enzyme-producing $\gamma$ Proteobacterium isolated from a cold and alkaline environment in Greenland. Syst Appl Microbiol 30, 197-201.
Swofford, D. L. (2002). PAUP ${ }^{\star}$ : Phylogenetic analysis using parsimony (* and other methods), version 4. Sunderland, MA: Sinauer Associates.

Thompson, J. D., Gibson, T. J., Plewniak, F., Jeanmougin, F. \& Higgins, D. G. (1997). The CLUSTAL_X windows interface: flexible strategies for multiple sequence alignment aided by quality analysis tools. Nucleic Acids Res 25, 4876-4882.

Tolson, D. L., Barrigar, D. L., McLean, R. J. C. \& Altman, E. (1995). Expression of a non-agglutinating fimbria by Proteus mirabilis. Infect Immun 63, 1127-1129.

Yoon, J.-H., Park, S. E., Kang, S.-J. \& Oh, T.-K. (2007). Rheinheimera aquimaris sp. nov., isolated from seawater of the East Sea in Korea. Int J Syst Evol Microbiol 57, 1386-1390. 